\title{
THE QUEST FOR CREDIBILITY AND OTHER MOTIVES FOR NEWS CONSUMPTION AMONG ETHNICALLY DIVERSE YOUTHS IN FLANDERS
}

\author{
A culture-centered approach
}

\author{
Hasibe Gezduci and Leen d'Haenens
}

\begin{abstract}
This study investigated online and offline news consumption among Turkish $(N=539)$, Moroccan $(N=482)$ and Flemish $(N=753)$ youngsters between the ages of 12 and 19 as well as the motivations behind their news use. The potentially explanatory role of culture-specific and sociodemographic antecedents was examined. The results showed that news plays a more prominent role in Moroccan and Turkish youngsters' lives than in that of native Flemish youth. A striking finding was that Dutch television news is primarily looked at, particularly by the Moroccans, for its perceived credibility and for its function as a guide through the world. Flemish youngsters' most prevalent motives for news consumption on television are its intriguing content as well as the information it provides to talk about with peers and family members.
\end{abstract}

KEYWORDS credibility; ethnic minorities; Flanders; motives; news consumption; youths

\section{Motives Behind News Consumption}

A number of questions are raised by the combination of the notions "youngsters" and "news." Are young people still interested at all in the news? After all, it looks as if today's youngsters are no longer patient enough to sit through the news bulletin until an item is presented that does catch their attention. Various studies depict young people as a socially indifferent group; they hardly ever read newspapers and do not turn instead to television news, and very few of them are members of a political party (Barnhurst \& Wartella, 1991; Buckingham, 1996; Cullingford, 1992; three successive rounds of The European Social Survey between 2002 and 2007). The use of printed media among the younger generation has drastically declined and the Internet is fast replacing television for all kinds of functions, including keeping abreast of the news (Buckingham, 2000a, 2000b; Mindich, 2005; successive time consumption studies by the Social \& Cultural Planning Office of the Netherlands, 2009). As far as supply goes, a rapidly changing media landscape is offering a multitude of channels with news and information, and boundaries between the various media types are blurring. However, young people lead busy lives: their fast pace of life is one factor determining if and when they will consume the news and information offered by the media mix. Dutch research undertaken by Costera Meijer, Adolfsson, and Van Vossen (2006) reveals that youngsters are interested in news, but only if a number of conditions are met: news must be reliable and show involvement, and it should be available any time of 
the day. The latter condition is, of course, met by online news. However, these data bear only on native Dutch youngsters living in the Netherlands.

What about the news and information requirements of ethnic minority youngsters, ${ }^{1}$ and in particular Turkish and Moroccan youngsters living in Flanders (the northern, Dutchspeaking half of Belgium) and growing up in at least two different socializing contexts? In their case the abundance of news and information is even greater due to an additional dimension: thanks to their bilingual upbringing, they also have access to news in the language of their parents' country of origin, as well as news in Dutch. Moreover, the social and cultural positioning of Turks and Moroccans vis-à-vis the host society significantly differs, generally depending on the strength of their religious affiliation. Traditionally, the Turkish community is characterized by stronger links with the home country, mirroring its political and secular versus religious strands of thought, as well as a greater degree of internal cohesion than the Moroccan community. So, in light of the above, we ask ourselves which choices they make, given the excess of news, and what their motives are for doing so, in light of their dual ethnic-cultural background. The latter question is the main subject of our research; that is, the motivations of youngsters, both those belonging to the ethnic minorities and those who are natives, ${ }^{2}$ for taking in news.

News is at the core of this study because it is still considered a major source of knowledge and attitudes, passing on the norms and values of a society to individuals (Gillespie, 1995; Johnson-Cartee, 2005), and because it is considered responsible, along with other factors, for the shaping of different ideologies, identities, and experiences (Gandy, 1998; Hall, Anten, \& Cakim, 1999; Robinson \& Levy, 1986). But it might very well be that one watches the news because it merely creates some kind of illusion of being informed (Buckingham, 2000b), of having fulfilled one's civic responsibility in a rather painless manner (Barnhurst \& Wartella, 1998; Graber, 1988). Buckingham (2000b) argues that young people may experience much less of this civic responsibility than adults, given their relative social powerlessness. Hence they are less likely to take in news. Dahlgren (1992) pleads in favor of a more culturalist, rather than a mere rationalistic, approach to news reception (i.e. away from the level of accuracy of the news reception in terms of recall and comprehension): the key question, according to him, has to do with the extent to which news succeeds in establishing its own credibility and coherence and therefore creates "forms of consciousness" and "structures of feeling." In line with this plea for looking for motivations of news consuming and the pleasures (or lack thereof) it involves, we look at news consumption by youngsters in terms of its potential in the building of social capital, such as civic engagement and social trust (Beaudoin \& Thorson, 2004; Putnam, 2000). In this context, consumption of news can be defined as community participation, in which "bridging" (i.e. building bridges into the host society) and "bonding" (i.e. strengthening intra-group solidarity) are to be considered as specific ethnic minority youths' selection criteria on news preferences that cannot be endorsed by their Flemish peers. In light of the above, we believe that culture-specific characteristics (i.e. language command, religious conviction, ethnic-cultural position) in addition to social-demographic characteristics (i.e. gender, age, schooling, socio-economic status) may play a central role in the needs and expectations of Turkish and Moroccan youths to consume offline and online news.

This study posits that Turkish and Moroccan youngsters' motives (i.e. looking for information to talk about with peers/family, to keep abreast of the latest events, for its perceived trustworthy and intriguing content, for entertainment, for social learning, and from a desire for the homeland) for offline and online news consumption are to be seen in 
the context of a variety of aspects consisting of culture-specific (i.e. their level of religiousness, their level of orientation toward the home country, language skills) alongside socio-demographic factors (i.e. gender, age, level of education, socio-economic status, length of residence in Belgium).

This leads us to the following research questions:

What are the motives of Turkish, Moroccan, and Flemish youngsters for turning to online and offline news?

Do we find mainly different or similar motives and expectations?

Do social-demographic and culture-specific characteristics offer an explanation for these motives?

\section{Predictors for Motives Behind News Preferences}

Departing from the audience as actively selecting media types and contents, a Uses and Gratifications approach (e.g. Katz, Blumler, \& Gurevitch, 1974) offers an instrumental theoretical frame to nail down youngsters' (both minority and majority) motives for consumption of offline and online news. Palmgreen and Rayburn (1985) remark that gratifications are not always obtained from media consumption itself, as motivations are reflective of the individual and of the social context in which one finds oneself.

\section{Socio-Demographics}

Research has shown that gender plays a significant role in explaining the differences in youngsters' perception of media contents. Boys and girls go about with media in different ways, which can be related to differences in socialization (e.g. Roe, 1998; Valkenburg \& Janssen, 1999). Boys are more interested in "hard" information, whereas girls tend to look for information with "pleasant" and "emotional" content (e.g. Raeymaeckers, 2003). Age also plays a role in media preferences. Roe's study (1998) revealed that as one gets older, information programs tend to be more positively evaluated. Furthermore, youngsters' level of education also plays a significant role: the higher one's level of education, the more one looks at news and informational programs. In addition, highly educated youngsters attest to a more diverse media choice (Clycq, Timmerman, \& Michielsens, 2005). Social class is not found to have a highly decisive influence on youngsters' content preferences (e.g. Garitaonandia, Juaristi, \& Oleaga, 2000).

\section{Culture-Specific Features}

Exposure to content is also constrained by a host of socio-cultural and psychological factors surrounding the decision to attend to media (e.g. McQuail, 2000; Wright, 1981). In other words, people's use of and needs for certain media messages differ in numerous ways due to their cultural backgrounds (i.e. belief systems, personal values, opinions, ethnicity, and attitudes). The impact of socio-cultural features is identified by d'Haenens, Van Summeren, Kokhuis, and Beentjes (2004) indicating that Turkish youths with a strong orientation toward Turkey consult the Internet more often for news on Turkey than on the country in which they live. On the contrary, Turkish youngsters with a weak orientation 
toward Turkey were found to consult the Internet more often for news on the society in which they live.

An additional influence that is expected to be associated with Turkish and Moroccans' media use is command of the home and host language. Research findings on bilingualism and media preferences in bicultural environments suggest that ethnic minorities prefer media in the language of origin, even after having spent significant time in a new country (Delener \& Neelankavil, 1990; Lee \& Tse, 1994). Ethnic minorities with lesser language skills watch more entertainment programs. Gezduci and d'Haenens's research (2007) among Turkish adults showed that command of Turkish leads to an increase in the consumption of Turkish news, whereas those with a high command of Dutch or French consume more Dutch or French news. In all, the potential interplay between television news and language acquisition in the lives of immigrant youngsters merits more research attention. Especially the function of television news as an alternative form of "schooling" and a source of social learning needs to be looked into (Lemish, 2007, p. 134). Religiousness also plays a significant role in media preferences: youngsters with a high level of religiousness used more online media than those showing less affinity with their religion (d'Haenens et al., 2004). The latter is also supported by the study of Gezduci \& d'Haenens (2007) on Turkish adults, which illustrates that the higher one's connectedness with religion and with Turkey, the more one tends to be interested in all kinds of news from Turkey.

So far, most research on ethnic minority audiences has focused its attention on media orientation with respect to demographic variables (e.g. age group, gender, and social classes) as the initial predictors of mass media use, whereas few attempts have been made to explain media preferences by one's socio-cultural environment. Moreover, research including the cultural dimension of ethnic minorities' media use is mostly based on limited, ad hoc samples in which the predictive value of ethnic-cultural variables is assessed in isolation as opposed to in competition with socio-demographic characteristics.

\section{Methodology: Data Collection, Instrument, and Sample Description}

In Flanders there is a striking lack of data on time consumption of media output among different audience groups. While, for instance, in their neighbor to the north, the Social and Cultural Planning Office of the Netherlands constitutes a rich resource of such data, in Flanders we had to recur to the self-reporting method through an ad hoc school survey. We are aware of the news category being a socially desirable genre to spend time with, but given the acute shortage of news use data among native Flemish youngsters and certainly among ethnic minority youths, ad hoc surveying proved to be the only achievable alternative.

Between February and May 2007 data collection took place in thirty Flemish secondary schools in four Flemish provinces, taking into account the urban concentrations of ethnic minorities and their different levels of education. Two versions of the questionnaire (one for the Flemish and one for the Turkish and Moroccan youngsters) were developed for completion in the classroom. The version for the latter group contained more questions on home and Dutch language media use and news consumption, and the motives behind it. On average, the questionnaire took 20 minutes to half an hour to complete. The survey aimed at obtaining preferences for media use in general (i.e. television, newspapers, and the Internet), in terms of their main functions (i.e. entertaining, informational, and communicative), for four news types in particular (i.e. financial and 
economical, social and legal topics, war and terrorism topics, and topics on religion), and the motives behind news consumption (i.e. to look for information to talk about with peers and family, to keep abreast of the latest events, for its perceived trustworthy and intriguing content, for entertainment, from a desire for the homeland). ${ }^{3}$

All media-related variables were measured on a five-point scale, in which a high score corresponded with a high level of use. Turkish and Moroccan youngsters additionally indicated on a five-point scale their use of the above media-related variables in the home language. Reliability analyses on the items containing news media-related practices in the Dutch language included ten items for each medium type (i.e. TV, the Internet, and newspapers) with a high Cronbach's alpha for all three groups under study: $\alpha_{\mathrm{TV}}=.887$, $\alpha_{\mathrm{ICT}}=.893, \alpha_{\mathrm{PRINT}}=.897$. The reliability analysis for news media-related practices in the home language of the Turkish and Moroccan youngsters included also ten items for all three media types and showed a high Cronbach's alpha for all groups: $\alpha_{\mathrm{TV}}=.878$, $\alpha_{\mathrm{ICT}}=.901, \alpha_{\text {PRINT }}=.919$.

The educational level and occupation of the father and the mother weighted as an index for the youngsters' socio-economic status (SES) and showed a good internal validity for the Turkish youngsters ( $\alpha=.682$ ), for the Moroccan youngsters $(\alpha=.672$ ), and for the Flemish youngsters ( $\alpha=.782$ ). Additionally, for the ethnic minority youngsters, their length of residence in Belgium, as well as culture-specific features such as religiosity, ethniccultural position, and use of both home and host language are included.

Questions about ethnic-cultural position were based on Van Heelsum's (1997) statements relating to the dimensions of cultural identity. Participants had to indicate to what extent they regard themselves as members of the Turkish/Moroccan community and to what extent they see themselves regarded and/or treated primarily by the majority of society as representatives of their own community. The statements used were based on self-identification (i.e. the extent to which the respondents feel or see themselves as Turkish/Moroccans), orientation toward Turkish/Moroccan people (i.e. the level of commitment toward Turkish/Moroccan society), orientation toward Belgian people (i.e. the level of commitment toward Belgian society), and contact with the own group. These statements were measured on a five-point scale ranging from 1 (strongly disagree) to 5 (strongly agree). High scores corresponded with a high level of involvement with the country of origin and the perception of great differences between one's own group and the Flemish majority group. The ethnic-cultural position measure included 15 items for which reliability analysis indicated a high Cronbach's alpha coefficient of .826 for the Turkish group and a high Cronbach's alpha coefficient of .840 for the Moroccan group.

Religiousness was looked at from different angles asking several questions inspired by Kemper's (1996) dimensions of religious identity. These questions looked into the respondents' attitudes toward the following dimensions: the ritual dimension (i.e. the level of participation in Islamic rituals), the intellectual dimension (i.e. knowledge of the five pillars of Islam), the social dimension (i.e. meetings within certain groups of believers), the ideological dimension (i.e. level of agreement with fundamentalism, Shari'a), and the consequential dimension (i.e. practicing Islamic norms and values, such as marriage preferences, social control, and halal/haram issues). The religiousness construct, which contained sixteen items, measured on a five-point scale and coded so that a high score corresponded with a high level of religion, showed a high reliability of .875 for the Turkish group and a high Cronbach's alpha coefficient of .887 for the Moroccan group. 
Finally, the survey also contained questions on language competence in the home context of both home and host languages among ethnic minority youngsters. A five-point Likert-scale was used: high scores corresponded with a high level of command of the language in question. Reliability analysis with regard to the four items measuring command of the Dutch language showed a Cronbach's alpha coefficient of .732 for the Turkish group and .760 for the Moroccan group. The four items measuring command of the home language showed a Cronbach's alpha coefficient of .793 for the Turkish group and .770 for the Moroccan group.

\section{Sample}

Table 1 shows the overall characteristics of our sample: 1,774 youngsters between the ages of 12 and 19 participated, among which 539 Turkish (30.4 per cent), 482 Moroccan (27.2 per cent), and 753 Flemish (42.5 per cent) youngsters, with comparable distributions of girls and boys, and an average age of 15 years.

A majority of the youngsters under study are enrolled in vocational and technical education. Levels of SES (measured on a five-point scale) were recoded into three categories (low, medium, and high). Note that the majority of the Flemish youngsters belong to more affluent families than the majority of Turkish and Moroccan youngsters, the latter implying higher levels of unemployment and blue-collar positions of the parents. Another eye catcher is the percentage of newcomers among Moroccan youth (18.7 per cent), higher than that of Turkish newcomers (10.8 per cent).

With respect to culture-specific features, differences between Turkish and Moroccan youths prevail, except for the youngsters' level of religiousness (Table 2). It is remarkable

\section{TABLE 1}

Socio-demographic features of the sample

\begin{tabular}{|c|c|c|c|c|c|c|c|}
\hline \multicolumn{2}{|l|}{ Country of origin } & \multicolumn{2}{|c|}{ Morocco } & \multicolumn{2}{|c|}{ Turkey } & \multicolumn{2}{|c|}{ Flanders } \\
\hline & & $N$ & $\%$ & $N$ & $\%$ & $N$ & $\%$ \\
\hline & & 482 & 27.2 & 539 & 30.4 & 753 & 42.5 \\
\hline \multirow[t]{2}{*}{ Gender } & $1=$ Male & 235 & 48.8 & 273 & 50.6 & 408 & 54.2 \\
\hline & $2=$ Female & 247 & 51.2 & 266 & 49.4 & 345 & 45.8 \\
\hline \multirow[t]{3}{*}{ Age } & $1=<=14$ & 190 & 39.4 & 204 & 37.9 & 285 & 37.8 \\
\hline & $2=$ Between 15 to $16 \mathrm{yrs}$ & 138 & 28.6 & 177 & 32.8 & 305 & 40.5 \\
\hline & $3=$ Older than 17 & 154 & 32.0 & 158 & 29.3 & 163 & 21.6 \\
\hline \multirow[t]{3}{*}{ Education } & $1=$ Low & 249 & 51.7 & 238 & 44.2 & 343 & 45.6 \\
\hline & $2=$ Medium & 97 & 20.1 & 131 & 24.3 & 148 & 19.7 \\
\hline & $3=$ High & 136 & 28.2 & 169 & 31.4 & 261 & 34.7 \\
\hline \multirow[t]{3}{*}{ Socio-economic status } & $1=$ Low & 263 & 54.6 & 295 & 54.7 & 110 & 14.6 \\
\hline & $2=$ Medium & 133 & 27.6 & 170 & 31.5 & 287 & 38.1 \\
\hline & $3=$ High & 85 & 17.6 & 74 & 13.7 & 356 & 47.3 \\
\hline Length of residence in & $1=<=2$ years & 11 & 2.3 & 11 & 2.0 & na & na \\
\hline \multirow[t]{4}{*}{ Belgium } & $2=$ Between 3 to 6 yrs & 44 & 9.1 & 17 & 3.2 & na & na \\
\hline & $3=$ Between 7 to 11 years & 21 & 4.4 & 13 & 2.4 & na & na \\
\hline & $4=$ More than 12 years & 14 & 2.9 & 17 & 3.2 & na & na \\
\hline & $5=$ Born in Belgium & 392 & 81.3 & 481 & 89.2 & na & na \\
\hline
\end{tabular}

Note: na $=$ not applicable. 
TABLE 2

Culture-specific features of the sample

\begin{tabular}{lcc}
\hline & $\begin{array}{c}\text { Moroccans } \\
\mathbf{N}=\mathbf{4 8 2}\end{array}$ & $\begin{array}{c}\text { Turks } \\
\mathbf{N}=\mathbf{5 3 9} \\
\mathbf{X}\end{array}$ \\
& $\mathbf{X}$ & 2.84 \\
Use of the Dutch language & 3.28 & 3.81 \\
Use of the language of the country of origin & 2.94 & 2.97 \\
Religiousness & 2.98 & 4.01 \\
Ethnic-cultural position & 3.79 & \\
\hline
\end{tabular}

Note: $\mathrm{X}=$ average values of media use measured on a five-point scale $(1=$ not $/$ never, $2=$ weak/rarely,

$3=$ moderate, $4=$ strong, $5=$ very strong).

that Moroccan youngsters use the Dutch language more often than their Turkish peers, who on the contrary more often use Turkish on a daily basis. Furthermore, differences are also visible in terms of affinity toward the homeland: Turkish youngsters show a higher level of affinity with their homeland than their Moroccan peers. Regarding Turkish and Moroccan youngsters' religiousness, Table 2 shows that the majority see themselves as moderately religious.

\section{Results}

The following sections present the main results in the field of news consumption. Apart from the general discussion of news consumption and the motives underlying it, significant differences between the three groups are looked into, using univariate regressions. The group of ethnic minority youths is looked at from a complementary angle, that is, news consumption in the language of their country of origin, on the one hand, and motives for turning to that kind of news on the other. Furthermore, by means of multivariate regression analyses, the relative impact of socio-demographic and culturespecific characteristics on youngsters' motives for consuming news is elaborated upon.

\section{Offline and Online Media Use}

As a result of self-reporting, among the three media types under study, television in Dutch on average, expressed in hours per weekday, continues to occupy a prominent spot on the media menu of ethnic minority youngsters: Moroccan youngsters watch Dutch television for about 3 hours 57 minutes, while Turkish youngsters watch on average 3 hours 1 minute per weekday. Flemish youngsters spend a considerable amount of time in front of the computer ( 3 hours 42 minutes), which is considerably more than in front of the television set ( 2 hours 11 minutes). Moroccan and Turkish youngsters in turn spend less time with the PC (respectively, 3 hours 40 minutes and 3 hours 2 minutes per weekday). Newspapers in Dutch appear to be the least consulted medium among all three groups, although they continue to be by far more read by the Flemish youngsters ( $M R=32$ minutes, $\mathrm{TR}=27$ minutes, $\mathrm{FL}=0$ hour 45 minutes per weekday).

For media use in the language of the country of origin, we notice that Turkish and Moroccan youngsters spend more time in front of the television ( $\mathrm{TV}_{\mathrm{MR}}=3$ hours 2 minutes, $\mathrm{TV}_{\mathrm{TR}}=4$ hours 37 minutes per weekday) than using the Internet $\left(\mathrm{ICT}_{\mathrm{MR}}=2\right.$ hours 16 minutes, $\mathrm{ICT}_{\mathrm{TR}}=3$ hours 12 minutes per weekday) or reading newspapers (PRINT $\mathrm{MR}=0$ 
hour 15 minutes, $\mathrm{PRINT}_{\mathrm{TR}}=0$ hour 32 minutes per weekday). Briefly, we can state that Turkish youngsters are the "champions" when considering both home and host language media consumption. Moreover, Turkish, more so than Moroccan youngsters, use media in the language of the country of origin. This confirms Turkish youngsters' interest in and knowledge of their home language.

\section{Offline and Online News Consumption}

News, in Dutch or in the home language, is mostly consumed through television, followed by newspapers and the Internet: this is the ranking for all three groups under study (Table 3). Still, comparing the minority youths with the Flemish group, we find that the former consume more television news than the latter $(\beta=-.067, p \leq .01)$.

Moroccans consume more Dutch-language television and online news than Turks. Putting it differently, news consumption in the language of the country of origin is more usual among Turkish youths than among Moroccans.

\section{Recurrent Motives for Offline and Online News Consumption}

We will now look at our youngsters' motives for turning to offline and online news. A hierarchy in motives for taking in news will be drawn. In addition, Turkish and Moroccan youngsters' news consumption in the language of the country of origin will be examined in relation to their desire for their homeland as a possible motive. The average values of the various motives for Dutch-language and home language news consumption are listed on Tables 4 and 6 . Multivariate regression analyses show the varying impact of sociodemographics in competition with culture-specific characteristics on youngsters' motives for consuming Dutch-language and home news (see Tables 5 and 7). For the sake of clarity, only significant differences are commented upon.

\section{Recurrent Motives for News Consumption in Dutch}

What is striking with regard to Dutch-language television news consumption is the result that the need for topics to talk about, for surveillance, for reliable information, and for social learning, are more frequently mentioned by both ethnic minority groups than by the Flemish. By contrast, watching television news for interesting information is a motive more often marked by the Flemish (Table 4). It is the search for trustworthy information which turns ethnic minority youngsters to Dutch-language television news. This result is most evident among the Moroccan youths. On the contrary, the main motive leading Flemish youngsters to television news is the desire for interesting content. Among minority youngsters, this need is particularly manifest among the Moroccans. In all, the need for trustworthy information is the strongest predictor for all three groups under study.

Looking at the impact of socio-demographic and culture-specific characteristics on the motives for turning to Dutch television news (Table 5), we note that among the minority youths, watching television news for its reliable information is mainly mentioned by the older and more religious individuals. Furthermore, this motive is also cited by the Moroccan youngsters born in Belgium or who have been living there for quite some time, and by Turkish youngsters whose affinity with Turkey and Turkish is weak. In the Flemish 


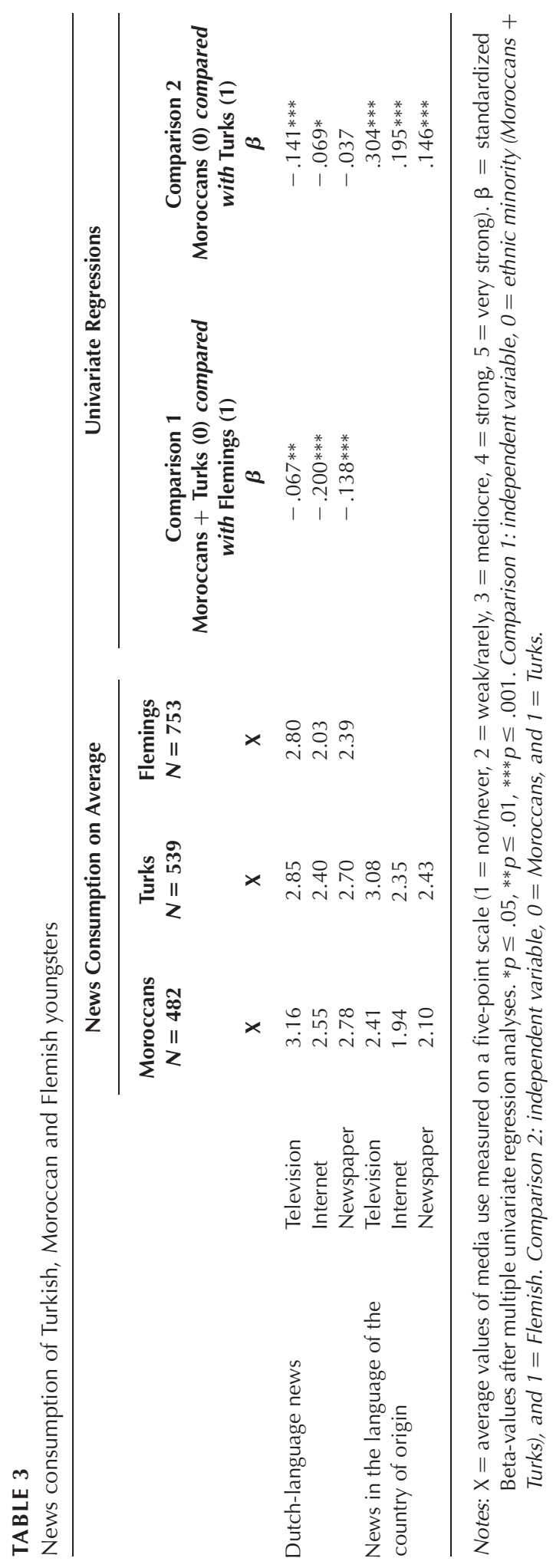


TABLE 4

Motives for offline and online Dutch-language news consumption

\begin{tabular}{|c|c|c|c|c|c|c|c|c|}
\hline & & \multicolumn{3}{|c|}{ Motives cited } & \multicolumn{4}{|c|}{ Univariate regressions } \\
\hline & & \multirow{2}{*}{$\begin{array}{c}\text { Mor. } \\
\text { X }\end{array}$} & \multirow{2}{*}{$\begin{array}{c}\text { Turks } \\
\text { X }\end{array}$} & \multirow{2}{*}{$\begin{array}{c}\text { Flem. } \\
\text { X }\end{array}$} & \multicolumn{2}{|c|}{$\begin{array}{l}\text { Comparison } 1 \\
\text { Moroccans }+ \\
\text { Turks (0) } \\
\text { compared with } \\
\text { Flemings (1) }\end{array}$} & \multicolumn{2}{|c|}{$\begin{array}{l}\text { Comparison } 2 \\
\text { Moroccans (0) } \\
\text { compared with } \\
\text { Turks (1) }\end{array}$} \\
\hline & & & & & $\beta$ & $\mathbf{R}^{2}$ & $\beta$ & $\mathbf{R}^{2}$ \\
\hline \multirow[t]{6}{*}{ TELEVISION } & Discussion & 3.03 & 2.98 & 2.86 & -.063 & & -.036 & \\
\hline & Surveillance & 3.19 & 3.23 & 3.09 & -.081 & & -.041 & \\
\hline & Reliability & 4.13 & 3.81 & 2.75 & $-.504 * * *$ & .254 & $-.158 * * *$ & .025 \\
\hline & Interesting & 2.70 & 2.72 & 3.12 & $.289 * * *$ & .084 & .031 & \\
\hline & Entertaining & 2.03 & 2.04 & 2.04 & .00 & & .001 & \\
\hline & Social learning & 3.22 & 3.08 & 2.41 & $-.280 * * *$ & .078 & -.048 & \\
\hline \multirow[t]{6}{*}{ INTERNET } & Discussion & 3.01 & 2.98 & 2.86 & -.09 & & -.077 & \\
\hline & Surveillance & 3.41 & 3.74 & 3.07 & $-.259 *$ & .067 & $.193 * *$ & .037 \\
\hline & Reliability & 3.56 & 3.50 & 3.50 & -.05 & & -.092 & .004 \\
\hline & Interesting & 4.15 & 4.16 & 4.17 & .03 & & -.06 & \\
\hline & Entertaining & 2.99 & 2.85 & 2.84 & -.03 & & -.049 & \\
\hline & Social learning & 4.08 & 4.05 & 4.30 & $.243 *$ & .049 & -.034 & \\
\hline \multirow[t]{6}{*}{ NEWSPAPERS } & Discussion & 3.23 & 3.10 & 3.25 & .03 & & -.08 & \\
\hline & Surveillance & 3.52 & 3.49 & 4.15 & $.318^{* * *}$ & .101 & -.028 & \\
\hline & Reliability & 3.51 & 3.38 & 3.54 & .03 & & $-.068 *$ & .005 \\
\hline & Interesting & 3.62 & 3.60 & 2.58 & $-.133 * *$ & .018 & -.046 & \\
\hline & Entertaining & 2.52 & 2.50 & 2.52 & .00 & & -.01 & \\
\hline & Social learning & 2.68 & 2.65 & 2.68 & .01 & & -.02 & \\
\hline
\end{tabular}

Notes: $X=$ average values of the motives for news consumption measured on a five-point scale ( $1=$ not//never, $2=$ weak $/$ rarely, $3=$ mediocre, $4=$ strong, $5=$ very strong). $\beta=$ standardized Beta-values after multiple univariate regression analyses. $* p \leq .05, * * p \leq .01, * * * p \leq .001$. Comparison 1: independent variable, $\mathrm{O}=$ ethnic minority (Moroccans + Turks), and $1=$ Flemish. Comparison 2: independent variable, $0=$ Moroccans, and $1=$ Turks.

group the need for reliable information is generally mentioned by the girls and by the younger individuals.

Flemish girls, younger youths, and those with lower schooling levels tend to turn to Dutch-language television news for its perceived interesting nature. Among minority youths, Dutch-language television news consumption from this particular motive is mostly mentioned by those with a higher schooling level and those who do not speak the home language that often, as well as by the younger members of Moroccan origin.

Finally, turning to Dutch-language television news for social learning is most common among the more religious minority youths, as well as among younger Moroccan youths, born in Belgium or residing in Belgium for quite some time, who do not often speak Arabic/Berber, and whose affinity with Morocco is weak.

As far as online Dutch-language news consumption is concerned, Turkish and Moroccan youths turn to an online platform predominantly for its interesting content, whereas the main motive for Flemish youngsters to consult online news is to gratify their need for social learning, the latter being more cited by the Flemish than by their minority 


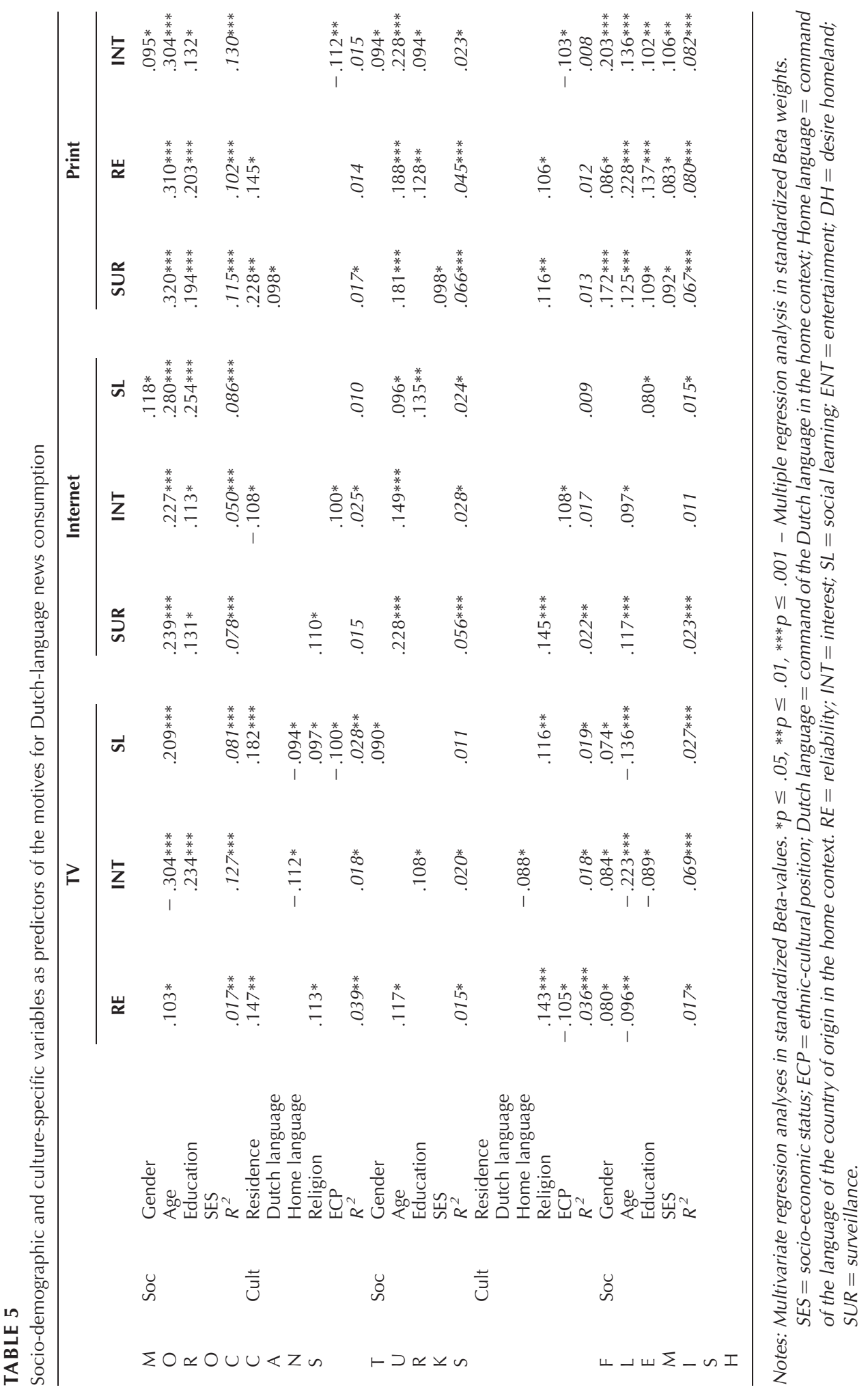


TABLE 6

Motives for offline and online news consumption in home language

\begin{tabular}{|c|c|c|c|c|c|}
\hline & & \multicolumn{2}{|c|}{ Motives Cited } & \multirow{2}{*}{\multicolumn{2}{|c|}{\begin{tabular}{l}
\multicolumn{1}{c}{$\begin{array}{c}\text { Univariate } \\
\text { Regressions }\end{array}$} \\
Comparison 1 \\
Moroccans (0) \\
compared \\
with Turks (1)
\end{tabular}}} \\
\hline & & \multirow{2}{*}{$\begin{array}{c}\text { Moroccans } \\
\text { X }\end{array}$} & \multirow{2}{*}{$\begin{array}{c}\text { Turks } \\
\text { X }\end{array}$} & & \\
\hline & & & & $\boldsymbol{\beta}$ & $R^{2}$ \\
\hline \multirow[t]{7}{*}{ TELEVISION } & Discussion & 3.26 & 3.29 & .03 & \\
\hline & Surveillance & 3.17 & 3.21 & .09 & \\
\hline & Reliability & 3.58 & 3.75 & $.140 * * *$ & .020 \\
\hline & Interesting & 2.98 & 3.03 & $.088 * * *$ & .008 \\
\hline & Entertaining & 3.04 & 3.09 & .03 & \\
\hline & Social learning & 2.58 & 3.25 & $.235 * * *$ & .055 \\
\hline & Desire for homeland & 3.75 & 4.04 & $.162 * * *$ & .026 \\
\hline \multirow[t]{7}{*}{ INTERNET } & Discussion & 2.74 & 2.84 & .070 & \\
\hline & Surveillance & 3.30 & 3.43 & .044 & \\
\hline & Reliability & 3.92 & 4.06 & $.065 *$ & .004 \\
\hline & Interesting & 3.11 & 3.25 & .053 & \\
\hline & Entertaining & 3.78 & 3.82 & .08 & \\
\hline & Social learning & 3.75 & 4.02 & $.117 * * *$ & .014 \\
\hline & Desire for homeland & 3.14 & 3.38 & $.047 *$ & .002 \\
\hline \multirow[t]{7}{*}{ NEWSPAPERS } & Discussion & 3.45 & 3.46 & .01 & \\
\hline & Surveillance & 2.74 & 3.16 & $.148 * * *$ & .022 \\
\hline & Reliability & 3.96 & 4.01 & .056 & \\
\hline & Interesting & 3.35 & 3.37 & .07 & \\
\hline & Entertaining & 3.72 & 3.73 & .001 & \\
\hline & Social learning & 2.03 & 2.05 & .001 & \\
\hline & Desire for homeland & 2.79 & 3.04 & $.09 * *$ & .008 \\
\hline
\end{tabular}

Notes: $X=$ average values of media use measured on a five-point scale $(1=$ not/never, $2=$ weak $/$ rarely, $3=$ mediocre, $4=$ strong, $5=$ very strong). $\beta=$ standardized Beta-values after multiple univariate regression analyses. $* p \leq .05, * * p \leq .01, * * * p \leq .001$. Comparison 1 : independent variable, $0=$ Moroccans, and $1=$ Turks.

peers. The need for social learning as the main reason for going online is mentioned by all older members of the three groups under study, by the Turkish and Moroccan youngsters with a high schooling level, and by the Moroccan girls.

In order to stay abreast of news on events in the world surrounding them (i.e. surveillance), Turkish and Moroccan youngsters consult online news more than the Flemish youth. When comparing both minority groups, Turkish youths more often turn to the Internet for this particular reason than their Moroccan peers. Those youngsters who mark surveillance for going online are slightly older, more religious, or Moroccan with a high education level.

The quest for interesting information links minority youths, more so than their Flemish peers, to Dutch newspapers; the need for surveillance, however, remains the main reason for Flemish youngsters and more so than for minority youths. Dutch-language newspapers as a source for interesting information prove to play no role at all for both ethnic minority groups. Still, results show that Moroccan youngsters read Dutch-language newspapers more often than their Turkish counterparts because of their reliability, 


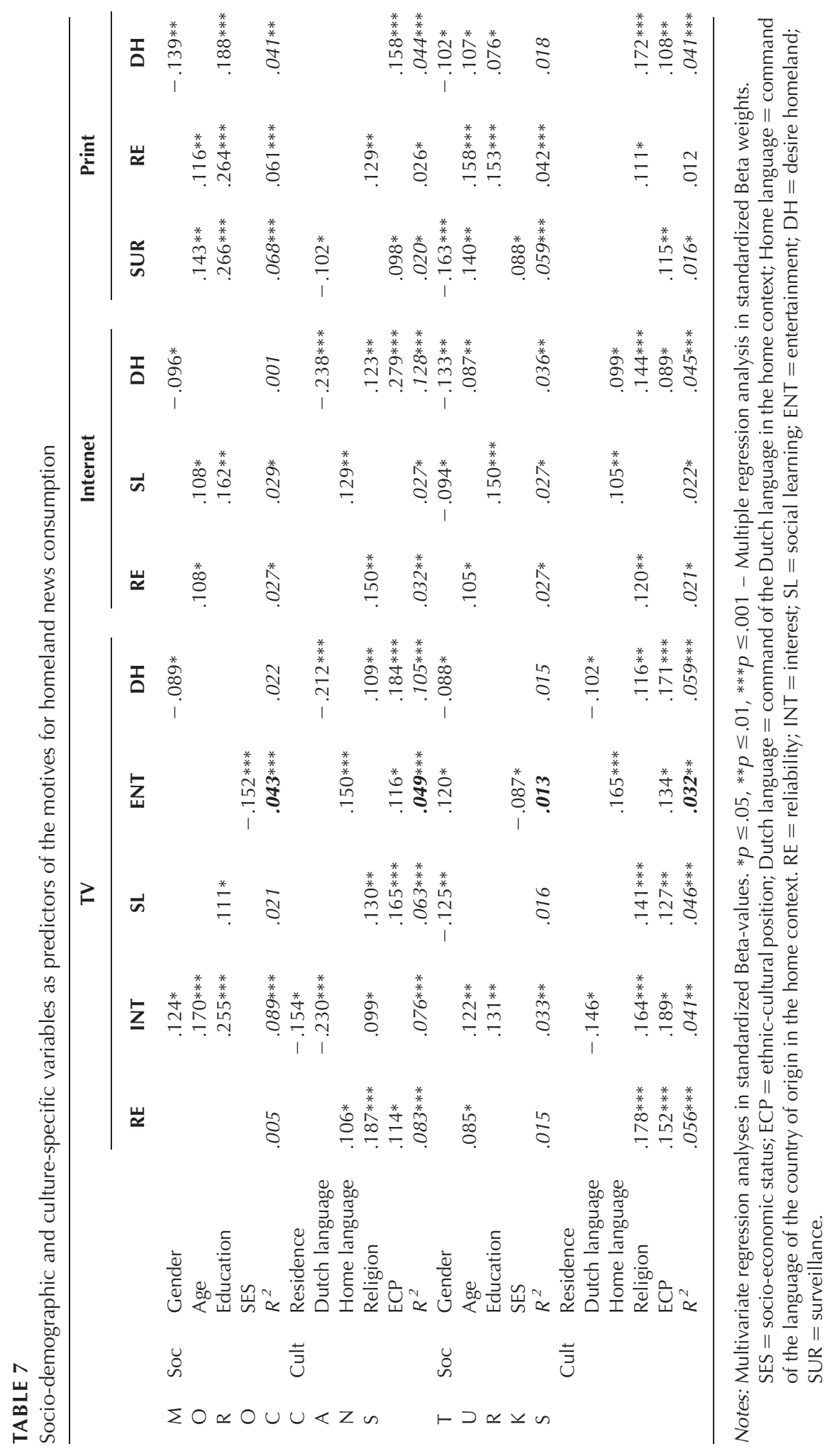


notwithstanding a very low predictive value. Those minority youngsters who do read Dutch-language newspapers for their interesting content are slightly older girls with a high schooling level and a weak affinity with their homeland.

Surveillance as the motive for reading Dutch-language newspapers among Moroccan youths is also mainly mentioned by the older members, by those with a high schooling level, who are born in Belgium or residing there for a long time, and who often speak Dutch. In addition, among the Turkish youths, Dutch-language newspapers for surveillance are mainly read by the older members, and by those who are more religious.

Concerning reliability as a motive for reading Dutch-language newspapers, we note that it is more often cited by the Turkish as well as the Moroccan older youngsters, and those with a high schooling level. Moreover, Dutch-language newspapers are also read for their reliable information by the more religious-oriented Turkish and Moroccan youths who are born in Belgium or have been living in Belgium for quite some time. In all, newspapers are predominantly read by Flemish, slightly older girls with a high schooling level, and from a more affluent family. The latter read newspapers for their interesting content and consider them as a tool for staying abreast of events in the world.

\section{Recurrent Motives for News Consumption in the Home Language}

Consumption of homeland news, although more predominant for the Turks, is mainly grounded in the need for reliable information, irrespective of the medium type (Table 6). The quest for interesting information appears to be the strongest predictor for diverging homeland television news consumption patterns. Social learning proves to be the strongest predictor for online news consumption. In contrast, homeland newspapers are mostly read for their guidance in the world (i.e. surveillance).

Watching television news in the homeland language for its perceived reliable content is cited by both Turkish and Moroccan youths who are more religious-minded and have a great affinity toward their country of origin, by the older group of the Turkish youths, and by the Moroccan youths who speak Arabic/Berber more often (Table 7).

Consumption of television news in the home language based on the desire to come across interesting information is predominantly mentioned by both Turkish and Moroccan youths who are slightly older, with a high schooling level, who use the Dutch language not that often, and who are more religiously oriented. In addition, homeland television news with this particular motive is mainly cited by Moroccan girls, those Moroccan youngsters who were not born or not lived a long time in Belgium, and Turkish youngsters with a great affinity toward Turkey.

Furthermore, watching homeland television news for social learning is a motive more often mentioned by Turkish as well as Moroccan youths who are more religious-minded and have a great affinity toward their homeland. This particular motive is also cited by the Moroccan youths with a high schooling level, and by the Turkish boys.

The last motive for turning to homeland television news which is significantly different among the two minority groups is the desire for the homeland, which is usually marked by both Turkish and Moroccan boys, who do not use the Dutch language often, who are more religious-minded and have a great affinity toward their country of origin.

As far as online news consumption in the language of the homeland is concerned, social learning as a motive is cited more often by both Turkish and Moroccan youths with a 
higher schooling level, and by those who often use the language of their country of origin. This motive is also cited more by the older Moroccan group, and by the Turkish boys. The need for reliable information as a motive for consulting online news in the home language is more evident among the older group and more religiously oriented Turkish and Moroccan youths. The desire for the homeland as a motive for watching non-Dutch online news is cited mainly by both Turkish and Moroccan boys and by those with a strong affinity for religion and for their country of origin. This particular motive is, moreover, mentioned slightly more often by Moroccan youngsters who usually speak Dutch less often, and by Turkish youngsters who have a high schooling level and use Turkish more often.

Finally, when ethnic minority youths read homeland newspapers for surveillance motives, it is mainly applicable to the older group of the ethnic minority youths, and those who are more oriented toward their country of origin. We notice, moreover, that this motive is also more evident among the Moroccan youths with a high schooling level and who more often speak Moroccan Arabic instead of Dutch, but also by the Turkish boys and by those from more privileged families. We notice, moreover, that the desire for the homeland as a motive for turning to news in the language of the country of origin, irrespective of the type of medium, is more often cited by the Turks than by the Moroccans, although the difference is not statistically significant. Even though no significant difference is found between the two groups of ethnic minority youths, it is worth mentioning that reading homeland newspapers for their reliable content is frequently cited by the older group, with a higher level of schooling, and also valuing religious principles highly.

\section{Discussion}

The research outlined above reveals how news can (or, as the case may be, cannot) function as a source of knowledge and attitudes, as a point of reference which passes on the norms and values of a given society to the group of young people under study. In all, for ethnic minorities, given their multifocal lives and their mixed feelings of belonging to their home as well as to their host countries, news media tend to play both a more complex and a more central role in their lives than for the native majority in acquiring an understanding of their host society, in keeping in touch with their home country and in using the media as a surrogate for direct experiences they are deprived of. In this respect home language news media play a complementary role, especially for slightly older ethnic minority youths who have an adequate command of their mother tongue and a great affinity for their country of origin. Present-day Dutch-language media do not quite satisfy this craving for news from Turkey and Morocco and therefore ethnic minority youths turn to intermediaries such as media from their homeland. This survey reveals a disconnection between the ethnic minority youths' broad set of news expectations on the one hand and the limited referentiality and meaningfulness of the Dutch-language news supply on the other.

Nevertheless, Dutch-language television news continues to fulfill a wide range of functions in the media menu of ethnic minority youngsters, more so than for native Flemish youths. The former group, and Moroccan youths in particular, unanimously mark reliability as the most important reason for watching Dutch-language television news, which is perceived as a guide through which they can better understand the world as well as the people around them, significantly more so than their Flemish peers. By contrast, their Flemish peers mention the interesting nature of the news as their overriding motive. 
Dutch-language television news, then, is multifunctional, and this contrasts sharply with the specific function of television news in the language of the country of origin: it is not the referential value of the latter that matters in the first place. What does matter is the link it represents with the homeland, and its reliable and entertaining character, especially in the view of those minority youths who still have a strong tie with their homeland and often speak Turkish or Moroccan Arabic.

Online news sites in Dutch are mainly turned to by the minority youngsters because of the interesting nature of these sites, while by contrast news sites in the language of the homeland are consulted mainly because of their reliability. Whereas online news is mainly consulted for social learning by Flemish youngsters, newspapers are primarily looked upon by those youngsters as a guide to the world around them. However, this is not the prime motive for ethnic minority youths, at least not if the newspaper is in Dutch: for them the newspaper must first and foremost be interesting. If they read a paper in the language of their homeland, they do so for its reliability. The latter motive probably applies especially to those youngsters with older relatives who can read newspapers in Arabic or are themselves a bit older and have adequate command of written Arabic. In brief, neither the newspapers in Dutch nor those in the language of the "homeland" can be regarded as guides for ethnic minority youngsters, even though this function is the overriding one for Flemish youngsters. This conclusion supports a finding put forward in previous research (d'Haenens, Beentjes, \& Bink, 2000); that is, the fact that ethnic minority youths do not recognize themselves in the Dutch-language media.

Proceeding on these findings as well as on the consideration that news not merely concerns the presentation of a given news item but is also felt to be a reality in itself, it is important to examine how news is perceived by Moroccans and Turks living in Flanders. Qualitative follow-up research will therefore focus on the reception of television news in general, and more particularly on how four different kinds of news (financial-economic topics, social-political and legal topics, war and terrorism, and religious topics) are interpreted when viewed in a family context. These particular news items have been chosen as they may reveal conflicting views when presented by Western or Flemish news media on the one hand, and Arabic, Moroccan, and Turkish news media on the other.

This follow-up study will be mainly concerned with evaluating the way in which the respondents construe the agendas behind the events reported, agendas which may well be at odds. The question will therefore be raised as to what extent the respondents regard television news as a means of social learning and what features of the news contribute most to that end.

Finally, with an eye to future research it needs to be stressed that the media should be able to gear their offer more expertly (i.e. with a thorough knowledge of the full range of the media menu) to the specific media needs of ethnic minority groups. For this purpose large-scale surveys based on representative samples and repeated at regular intervals are an absolute requisite. Continuous audience research based on a viewing monitor at the homes of a representative number of ethnic minority families (e.g. the numerically largest minority groups) is to be strongly recommended. We warmly welcome the initiatives now undertaken by the Audience Research Foundation in the Netherlands to try to include ethnic minority households in the viewing panel. Such initiatives require a major financial effort, all the more since at the same time the most important television channels watched by ethnic minorities also need to be covered in the monitoring. The Netherlands is the only country in the EU where we see such serious attempts to complement the continuous 
television audience panel with relevant ethnic minority groups and to broaden the range of television content happening.

\section{NOTES}

1. The term ethnic minority is to be understood as persons of whom at least one of the parents is of Turkish or Moroccan descent or was born in Turkey or Morocco.

2. Youngsters whose father and mother were born and bred in Flanders are here considered to be Flemish.

3. Central questions/statements in our questionnaire were, among others: "Which of the following media listed do you use in your room/elsewhere in the home?"; "I watch television because I find it a credible source/because I find it interesting/because I'm bored, etc."; "How do you consider yourself (in comparison with your peers) of issues related to education/politics/culture/religion/war and terror/laws on immigrants and minorities in Belgium/social regulation?"; "How often do you use the Internet?" followed by a set of options (to email with friends/family/to chat with friends/family/to consult news blogs/to search information on religion/to do homework, etc.).

\section{REFERENCES}

Barnhurst, K. G., \& Wartella, E. (1991). Newspapers and citizenship: Young adults' subjective experience of newspapers. Critical Studies in Mass Communication, 8, 40-58.

Barnhurst, K. G., \& Wartella, E. (1998). Young citizens, American TV newscasts and the collective memory. Critical Studies in Mass Communication, 15, 279-305.

Beaudoin, C. E., \& Thorson, E. (2004). Social capital in rural and urban communities: Testing differences in media effects and models. Journalism and Mass Communication Quarterly, $81,378-399$.

Buckingham, D. (1996). Moving images: Understanding children's emotional responses to television. Manchester: Manchester University Press.

Buckingham, D. (2000a). After the death of childhood: Growing up in the age of electronic media. Cambridge: Polity Press.

Buckingham, D. (2000b). The making of citizens: Young people, news and politics. London: Routledge.

Clycq, N., Timmerman, C., \& Michielsens, M. (2005). Allochtone nieuwszoekers: gebruik en evaluatie van televisienieuwsprogramma's en -zenders door jongvolwassen allochtonen [Migrant news grazers: Use and evaluation of television programs]. Tijdschrift voor Communicatiewetenschap, 33(2), 146-161.

Costera Meijer, I., Adolfsson, R., \& Van Vossen, M. (2006). De toekomst van het nieuws: hoe kunnen journalisten en programmamakers tegemoet komen aan de wensen en verlangens van tieners en twintigers op het gebied van pluriforme onafhankelijke informatievoorziening? [The future of the news: How can journalists and program makers meet the wishes of teenagers and those in their twenties in the field of pluriform independent news?]. Amsterdam: Otto Cramwinkel.

Cullingford, C. (1992). Children and society: Children's attitudes to politics and power. London: Cassell.

Dahlgren, P. (1992). Introduction. In P. Dahlgren \& C. Sparks (Eds.), Communication and citizenship (pp. 1-23). London: Routledge. 
Delener, N., \& Neelankavil, J. (1990). Informational sources and media usage: A comparison between Asian and Hispanic subcultures. Journal of Advertising Research, 30(3), 45-52.

d'Haenens, L., Beentjes, H., \& Bink, S. (2000). The media experience of ethnic minorities in the Netherlands. A qualitative study. Communications: The European Journal of Communication Research, 25(3), 325-341.

d'Haenens, L., Van Summeren, C., Kokhuis, M., \& Beentjes, H. (2004). Ownership and use of "old" and "new" media among ethnic minority youth in the Netherlands. The role of ethnocultural position. In K. Renckstorf, D. McQuail, J. E. Rosenbaum, \& G. Schaap (Eds.), Action theory and communication research. recent developments in Europe (pp. 315-344). Berlin/New York: Mouton de Gruyter.

Gandy, O. (1998). Communication and race: A structural perspective. London: Arnold.

Garitaonandia, C., Juaristi, P., \& Oleaga, J. A. (2001). Media genres and content preferences. In S. Livingstone \& M. Bovill (Eds.), Children and their changing media environment: A European comparative study (pp. 141-157). Mahwah, NJ: Erlbaum.

Gezduci, H., \& d'Haenens, L. (2007). Culture-specific features as determinants of news media use. Communications, 32(2), 193-222.

Gillespie, M. (1995). Television, ethnicity, and cultural change. New York: Routledge.

Graber, D. (1988). Processing the news: How people tame the information tide. New York: Longman.

Hall, A., Anten, T., \& Cakim, C. (1999). Perceived typicality: American television as seen by Mexicans, Turks, and Americans. Critical Studies in Mass Communication, 16(4), 436-455.

Johnson-Cartee, K. S. (2005). News narrative and news framing: Constructing political reality. Lanham, MD: Rowman and Littlefield.

Katz, E., Blumler, J. G., \& Gurevitch, M. (1974). Utilization of mass communication by the individual. In J. G. Blumler \& E. Katz (Eds.), The uses of mass communications: Current perspectives on gratifications research (pp. 19-32). Beverly Hills, CA: Sage.

Lee, W., \& Tse, D. (1994). Changing media consumption in a new home: Acculturation patterns among Hong Kong immigrants to Canada. Journal of Advertising, 23, 57-69.

Lemish, D. (2007). Children and television: A global perspective. Malden, MA: Blackwell Publishing. McQuail, D. (2000). Mass communication theory (4th ed.). London: Sage.

Mindich, D. (2005). Tuned out: Why Americans under 40 don't follow the news. New York: Oxford University Press.

Palmgreen, P., \& Rayburn, J. D. (1985). An expectancy-value approach to media gratifications. In K. E. Rosengren, L. A. Wenner, \& P. Palmgreen (Eds.), Media gratifications research: Current perspectives (pp. 61-72). Beverly Hills, CA: Sage.

Putnam, R. (2000). Bowling alone, the collapse and revival of civic America. New York: Simon and Schuster.

Raeymaeckers, K. (2003). De kloof tussen jongeren en nieuws [The gap between youth and news]. In D. Biltereyst \& Y. Peeren (Eds.), Nieuws, democratie en burgerschap. Onderzoek over hedendaagse nieuwsmedia (pp. 161-175). Gent: Academia Press.

Robinson, J. P., \& Levy, M. R. (1986). The main source: Learning from television news. Beverly Hills, CA: Sage.

Roe, K. (1998). Boys will be boys and girls will be girls: Changes in children's media use. European Journal of Communication, 23(1), 5-25.

Social and Cultural Planning Office of the Netherlands (2009). Retrieved March 2009, from http:// www.scp.nl/.

The European Social Survey. (2009). Retrieved March 2009, from http://ess.nsd.uib.no/. 
Valkenburg, P. M., \& Janssen, S. C. (1999). What do children value in entertainment programs? A cross cultural investigation. Journal of Communication, 49(2), 3-19.

Van Heelsum, A. J. (1997). De etnisch-culturele positie van de tweede generatie Surinamers [Ethniccultural position of the second generation of Surinamese]. Amsterdam: Het Spinhuis.

Wright, P. (1981). Cognitive responses to mass media advocacy. In R. E. Petty, T. M. Ostrom, \& T. C. Brock (Eds.), Cognitive responses in persuasion (pp. 263-282). Hillsdale, NJ: Erlbaum.

Hasibe Gezduci was a junior researcher at the Centre for Media Culture and Communication Technology at the Katholieke Universiteit Leuven, Belgium. This article was meant to be part of her $\mathrm{PhD}$ on news reception and meaning making by Turkish and Moroccan youngsters and adults. But fate decided otherwise: she suddenly passed away in winter 2007.

Leen d'Haenens is an Associate Professor at the Centre for Media Culture and Communication Technology of the Katholieke Universiteit Leuven, Belgium, and the Department of Communication Studies of the Radboud Universiteit Nijmegen, the Netherlands. Email: leen.dhaenens@soc.kuleuven.be orEmail: I.dhaenens@maw.ru.nl 
Copyright of Journal of Children \& Media is the property of Routledge and its content may not be copied or emailed to multiple sites or posted to a listserv without the copyright holder's express written permission. However, users may print, download, or email articles for individual use. 